DOI https://doi.org/10.18551/rjoas.2018-10.25

\title{
THE APPLICATION OF ORGANIC MATERIALS ON GROWTH OF EDIBLE CANNA (CANNA EDULIS KER) IN TIDAL SWAMP
}

\author{
Sulistyaningsih L.N., Susilawati, Setiyawan R.P. \\ Department of Agronomy, Faculty of Agriculture, University of Sriwijaya, Indonesia \\ ${ }^{*}$ E-mail: ninik sulistyaningsih@yahoo.com
}

\begin{abstract}
The research was aimed to evaluate the application of organic materials on growth and development of edible canna plant (Canna edulis Ker) in tidal swamp land. It was conducted in Suka Tani Village, Tanjung Lago Sub-district of Banyuasin from October 2017 to January 2018. Randomized Block Design was used with 6 treatments and 3 replicates. Each experimental unit consisted of 16 plants. The treatments consisted of $\mathrm{P}_{0}$ (control: without applying any organic matter), $\mathrm{P}_{1}$ (10 ton ha ${ }^{-1}$ of cow manure), $\mathrm{P}_{2}$ (15 ton ha ${ }^{-1}$ of rice husk ash), $P_{3}\left(20\right.$ ton ha ${ }^{-1}$ of of rice husk ash), $P_{4}$ (10 ton ha ${ }^{-1}$ of rice husk), and $P_{5}$ (15 ton ha ${ }^{-1}$ of rice husk). Results showed that the application of $\mathrm{P}_{2}$ (15 ton ha ${ }^{-1}$ of rice husk ash) could increase growth and development of edible canna plants. Highest results was found in the parameters of bud initiation time, plant height, flowering time, tiller number, plant fresh weight, plant dry weight, and corm weight.
\end{abstract}

\section{KEY WORDS}

Edible canna, organic matter, tidal swamp.

One of the main constraints for food sufficiency program is the uneven ratio between population growth and food production where the increase in population is much faster. It is even worsen by the decrease in agriculture cultivation areas. Indonesia actually has a potency to develop various kinds of food crops, unfortunately due to limited productive agricultural land, crop cultivation in marginal land has led to the decrease in productivity which in turn decreasing the food supply for the rapidly increasing population.

Food diversity is then needed to lessen the dependency on one specific food crop. While in local farmer level, it is known in term of multiculture and multi-commodities agriculture. Tuber food crops such as edible canna (Canna edulis Ker) has a great potency to be utilized as an alternative food crops. Edible canna corm is known as a safe and healthy local food source, however, it has not been cultivated widely. In South Sumatra, it is only known by the elderly and can be found uncultivatedly in several locations either in upland or in lowland area.

Due to its unpopularity, edible canna cultivation in optimal land has not been commonly found as rice and corn still become the priority crops. Thus, the cultivation of edible canna is more likely carried out in the sub-optimal land, such as in tidal swamp area. Total tidal swamp in Indonesia is around 20.14 millions ha distributed in 17 provinces in which 9.53 millions ha of the total is considered potential for agricultural activities. Total 5.27 millions ha are already used by either government transmigration program with 2.27 millions ha or by local community usages with 3.0 millions ha (Agricultural Land Research and Development Center, 2011).

Tidal swamp is an underused potential agro-ecologycal area for its large coverage, especially for food crop cultivation (Haryono, 2013). Furthermore, it is categorized into four main typologies based on the physco-chemical soil properties, such as (1) potential land, (2) acid sulphate land (either potential acid sulphate or actual acid sulphate), (3) peat land (peaty land, shallow peat, medium peat, deep peat, very deep peat), and (4) saline land.

Plant productivity can be increased by the addition of organic materials in the soil. The application of organic materials in a significant amount are conducted in the very first step of plant cultivation as it serves as basal fertilizer. The application of organic fertilizer and its 
combination is believed will increase both plant biomass and soil nutrient content compared to chemical NPK fertilizer (Das et al., 2007).

Rice husk, rice husk ash and cow manure are the most common organic materials been applied to the soil. Rice husk is usually a waste from rice milling process while rice husk ash is the husks that have been burned to ash. Manure has considerably better properties compared to either organic or inorganic fertilizers though it has slower effect to the plant regarding some changing process that it has to undergo (Suyatno, 2004).

Similar to other plant biomass, rice husk also contains lignocellulose material but with higher silica percentage. The chemical content of rice husk consists of $50 \%$ cellulose, 25$30 \%$ lignin, and $15-20 \%$ silica (Ismail and Waliuddin, 1996). Rice husk ash contains several nutrients with the composition of $0.15 \%$ nitrogen, $0.16 \%$ phosphorus, $1.85 \%$ potassium, $0.49 \%$ calcium, $1.05 \%$ organic carbon, $68.7 \% \mathrm{SiO}_{2}$ and $\mathrm{C} / \mathrm{N} 36$ (Sigit, 1984).

Martanto (2001) stated that rice husk is an organic material containing cellulose, lignin, and hemicellulose, and if being burned it can produce ash with high silica content for about $87 \%-97 \%$, and also contain $1 \%$ nitrogen and $2 \%$ potassium. Furthermore, potassium is needed to strengthen plant body in order to maintain leaves and flowers for not falling down, to regulate transpiration, to maintain enzymes mechanisms, to maintain osmotic potential and water absorbtion, to stimulate root hairs formation, to harden plant stems, and to stimulate seeds formation while silica is functioned as a growth booster of some gramineae plants, especially if given in optimal concentration dosage.

Research finding by Andayani and Sarido (2013) discovered that cow manure contained $2.33 \%$ nitrogen, $0.61 \%$ phosphorus $\left(\mathrm{P}_{2} \mathrm{O}_{5}\right), 1.58 \%$ potassium $\left(\mathrm{K}_{2} \mathrm{O}\right), 0.33 \%$ magnesium, $26.28 \%$ water content, $6.62 \%$ organic carbon, $0.65 \%$ total $\mathrm{N}, 10,18 \mathrm{C} / \mathrm{N}$ ratio, $11.41 \%$ organic content, $3.42 \%$ humic acid, and $2.92 \%$ fulvic acid. Furthermore, Novia (2015) concluded that the application of 15 ton ha $\mathrm{ha}^{-1}$ of cow manure on sweet potato showed best results in growth parameters such as fruit bud number, tuber length, tuber weight per plant and tuber weight per plot.

Thus, this research was conducted with the aim to evaluate the application of organic materials on growth of edible canna (Canna edulis Ker) in tidal swamp land.

\section{METHODS OF RESEARCH}

The research was conducted from September 2017 January 2018 in Suka Tani Village, Tanjung Lago sub-disctrict in Banyuasin while plant analysis was carried out in the Laboratory of Plant Physiology in Department of Agronomy, Faculty of Agriculture, University of Sriwijaya.

Randomized Block Design was used with 6 treatments and 3 replicates with 16 plants per unit resulting in total 288 plants. The treatments consisted of $\mathrm{P}_{0}=$ control, $\mathrm{P}_{1}=10$ ton ha ${ }^{-1}$ cow manure $\left(9 \mathrm{~kg} \mathrm{plot}^{-1}\right), \mathrm{P}_{2}=15$ ton ha ${ }^{-1}$ rice husk ash $\left(13.5 \mathrm{~kg} \mathrm{plot}^{-1}\right), \mathrm{P}_{3}=20$ ton ha ${ }^{-1}$ rice husk ash $\left(18 \mathrm{~kg} \mathrm{plot}^{-1}\right), \mathrm{P}_{4}=10$ ton ha ${ }^{-1}$ rice husk $\left(9 \mathrm{~kg} \mathrm{plot}^{-1}\right), \mathrm{P}_{5}=15$ ton ha ${ }^{-1}$ rice husk $(13.5$ $\mathrm{kg} \mathrm{plot}^{-1}$ ). Analysis of Variance (ANOVA) and least significant difference test was used for data analyzing.

Land was first cleared from the vegetation and then 18 plots by the size of $3 \mathrm{~m} \times 3 \mathrm{~m}$ with $50 \mathrm{~cm}$ spaces between each plot were prepared. Planting materials were selected from fresh canna rhizomes with the age of 6-8 months with no defect and free from disease. The application of organic materials was carried out a week before planting according to each treatment dosage. The rhizomes were planted in $10 \mathrm{~cm} \times 10 \mathrm{~cm}$ planting holes with $70 \mathrm{~cm} \times$ $70 \mathrm{~cm}$ planting space. Plants were maintained with sufficient water supply and kept free from weed competition. Harvest was perfomed at 5 months after planting by digging the corm from the soil.

The parameters consisted of bud initiation time, plant height $(\mathrm{cm})$, leaf number per clump, flowering time, leaf chlorophyll, tiller number, plant fresh weight, plant dry weight and fresh corm weight per clump. 


\section{RESULTS OF STUDY}

The analysis of variance indicated that the application of organic materials on edible canna plant showed significant effect on flowering time and non significant effect on the other parameters as seen in Table 1.

Table 1 - Analysis of variance on growth parameters of edible canna

\begin{tabular}{lll}
\hline Parameter & F-value & Coefficient of variance (\%) \\
\hline Bud initiation time & $2.61^{\mathrm{ns}}$ & 12.42 \\
Plant height $(\mathrm{cm})$ & $1.24^{\mathrm{ns}}$ & 18.48 \\
Leaf number & $0.67^{\mathrm{ns}}$ & 12.69 \\
Flowering time & $4.30^{*}$ & 3.16 \\
Tiller number & $3.12^{\mathrm{ns}}$ & 22.80 \\
Leaf chlorophyll & $1.36^{\mathrm{ns}}$ & 15.93 \\
Plant fresh weight per clump (g) & $1.87^{\mathrm{ns}}$ & 45.84 \\
Plant dry weight per clump (g) & $1.86^{\mathrm{ns}}$ & 58.74 \\
Corm weight per clump (g) & $1.87^{\mathrm{ns}}$ & 50.75 \\
\hline F0.05 & 3.33 & \\
F0.01 & 5.64 & \\
\hline
\end{tabular}

Note: * significantly difference; $n s=$ non significant.

The application of organic materials resulted non significant effect on bud initiation time. However, $\mathrm{P}_{2}$ showed the fastest bud initiation time with the average of 8 days after planting, while the lowest was in $\mathrm{P}_{5}$ with 12 days after planting (Figure 1).

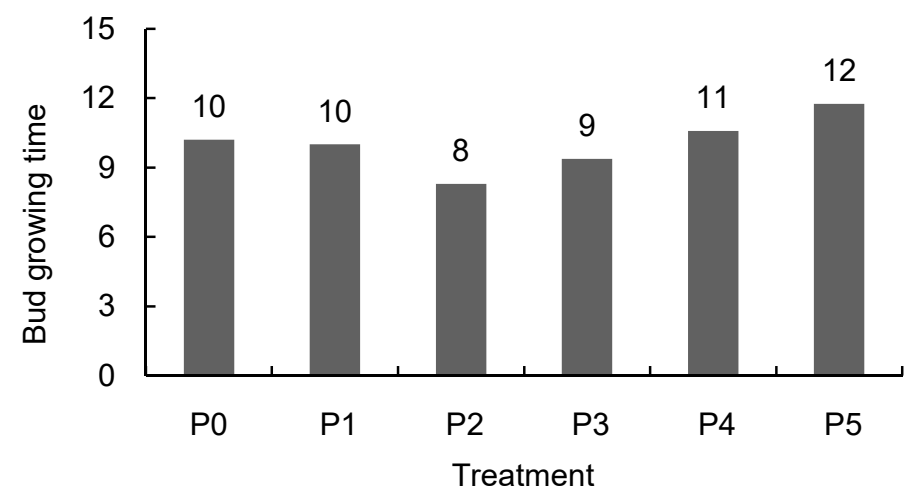

Figure 1 - The application of organic materials on bud initiation time of edible canna

Figure 2 shows the effect of organic materials application on plant height of edible canna. The highest plant height was obtained from $\mathrm{P}_{2}$ with the average of $87.42 \mathrm{~cm}$ while the shortest was $64.38 \mathrm{~cm}$ in $\mathrm{P}_{4}$. Figure 3 shows the increase in plant height per week.

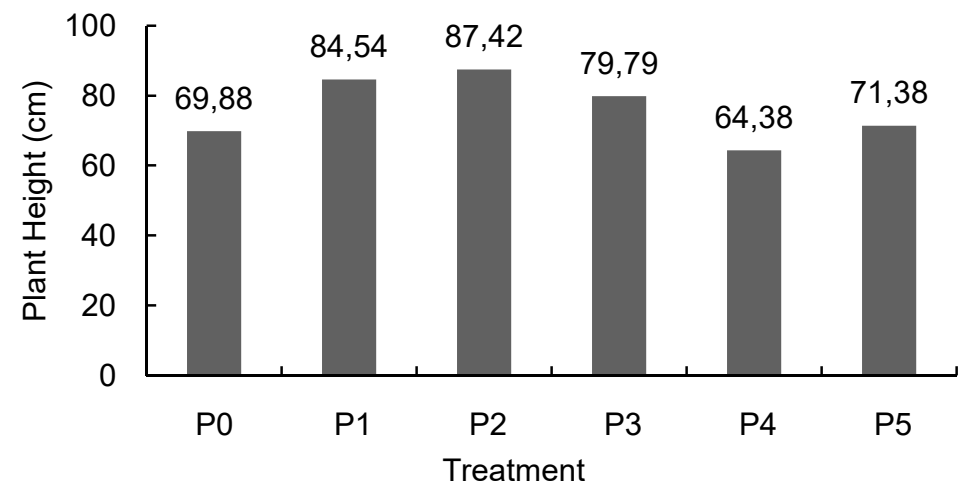

Figure 2 - The application of organic materials on plant height of edible canna 


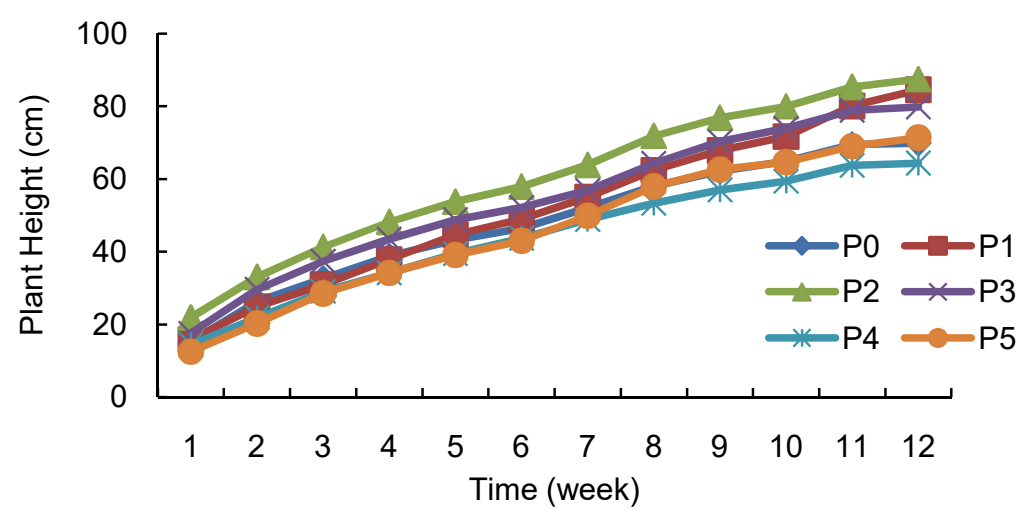

Figure 3 - The increase on plant height of edible canna

Leaf number also showed no significant effect from the application of organic materials. Yet, $\mathrm{P}_{3}$ treatment showed better performance by having more leaf number compared to other treatments with the average of 9.13 , and the lowest leaf number was 7.67 in $\mathrm{P}_{4}$ as given in Figure 4. Figure 5 shows the increase of leaf number per week.

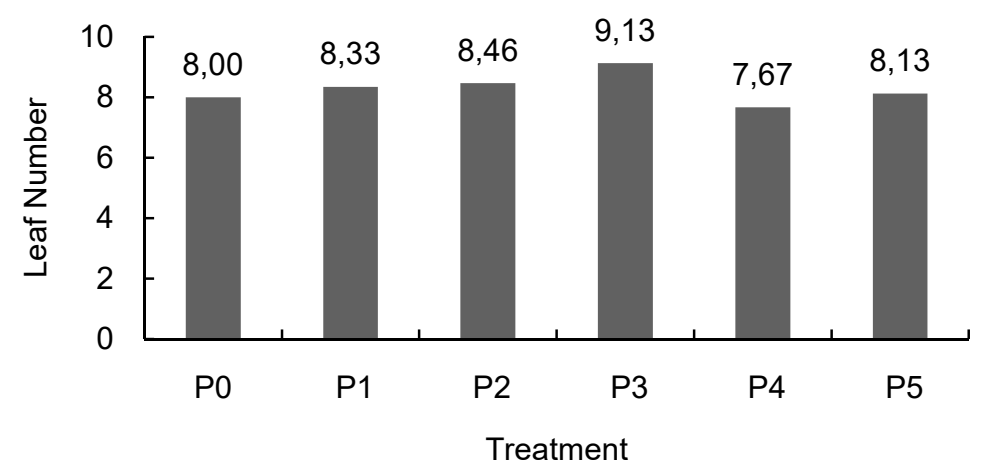

Figure 4 - The application of organic materials on leaf number of edible canna

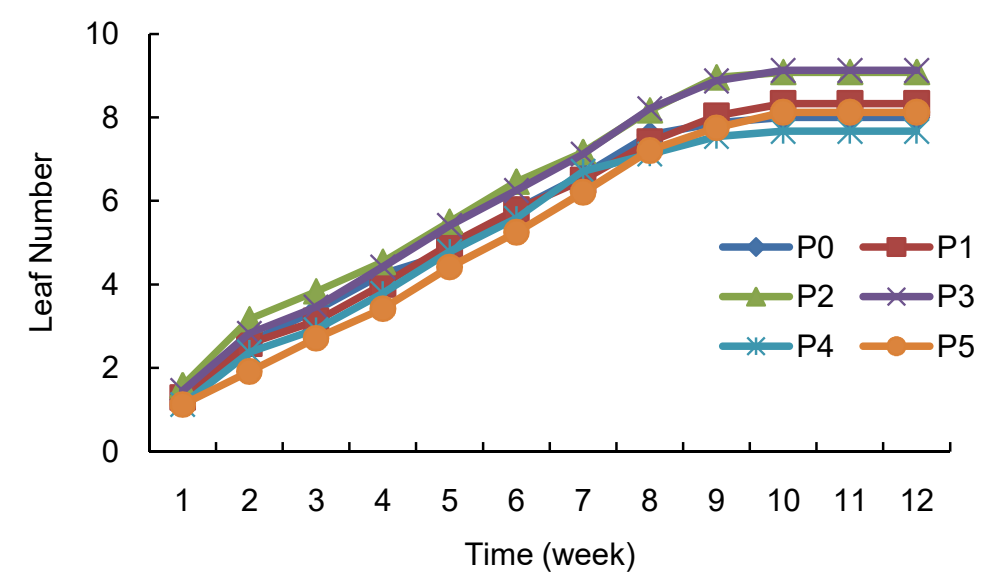

Figure 5 - The increase on leaf number of edible canna

Based on the analysis of variance, the application of organic materials showd a significant effect on flowering time of edible canna. Least significant difference then was tested as seen in Table 2. It shows that there is no significant difference between $P_{2}$ and $P_{3}$.

Despite of non significant results on analysis of variance, treatment $P_{2}$ shows best result in the parameter of final tiller number per clump with 5 tillers per clump, while the lowest was obtained in both $\mathrm{P}_{0}$ and $\mathrm{P}_{4}$ with 3 tiller per clump (Figure 6). 
Table 2 - Least significant difference test on flowering time of edible canna

\begin{tabular}{ccc}
\hline Treatment & Means & LSD 5\% $=5.74$ \\
\hline $\mathrm{P}_{0}$ & 101 & $\mathrm{a}$ \\
$\mathrm{P}_{1}$ & 103 & $\mathrm{a}$ \\
$\mathrm{P}_{2}$ & 95 & $\mathrm{~b}$ \\
$\mathrm{P}_{3}$ & 96 & $\mathrm{~b}$ \\
$\mathrm{P}_{4}$ & 103 & $\mathrm{a}$ \\
$\mathrm{P}_{5}$ & 100 & $\mathrm{a}$ \\
\hline
\end{tabular}

Means following by the same letter denotes a non significant difference on $5 \%$ of LSD test.

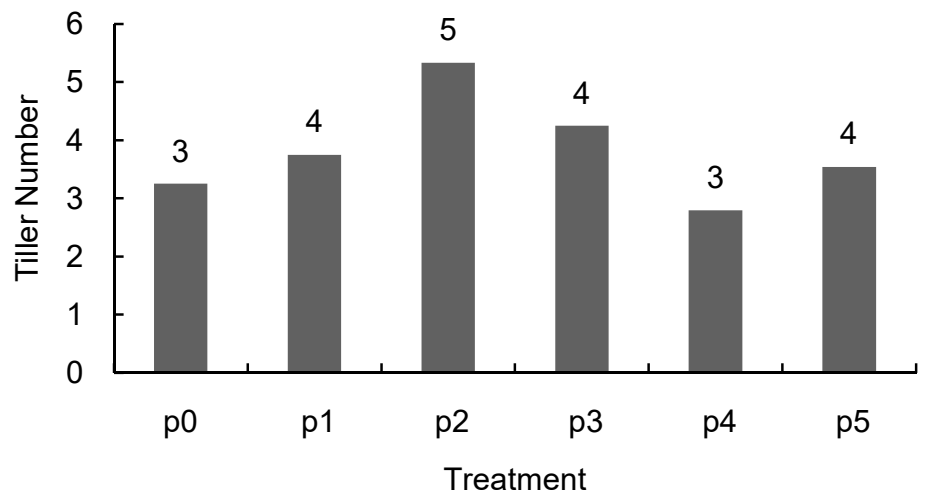

Figure 6 - The application of organic materials on tiller number per clump of edible canna

Leaf chlorophyll also showed no significant effect to the application of organic materials based on analysis of variance. However, Figure 7 indicated that $\mathrm{P}_{4}$ has the highest average of leaf chlorophyll with 16.78 and the lowest was 12.79 in $\mathrm{P}_{2}$.

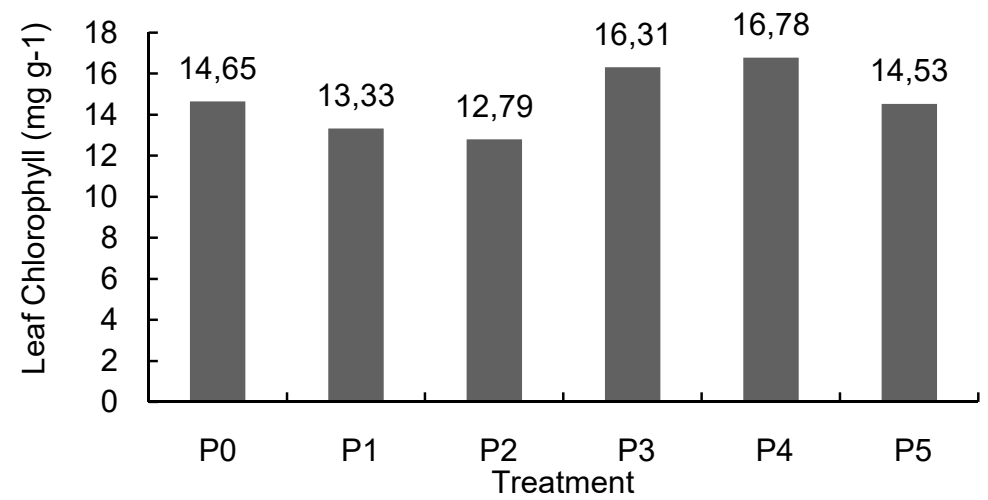

Figure 7 - The application of organic materials on leaf chlorophyll of edible canna

Analysis of variance resulted non significant effect of organic materials application on plant fresh weight per clump. Figure 8 shows that $P_{2}$ treatment has the highest average of plant fresh weight per clump with $499 \mathrm{~g}$ while the lowest is in $\mathrm{P}_{4}$ with the average of $182 \mathrm{~g}$.

Similar result was also found in plant dry weight per clump, analysis of variance showed no significant difference, however the effect of organic materials application can be seen in Figure 9. It indicates that $P_{2}$ has the highest average of plant dry weight with $158 \mathrm{~g}$ and the lowest is in $\mathrm{P}_{4}$ with $42 \mathrm{~g}$.

The application of organic materials also did not give any significant effect on corm weight per clump. The highest weight of corm per clump was obtained in $\mathrm{P}_{2}$ treatment with $271 \mathrm{~g}$, and the lowest was $77 \mathrm{~g}$ in $\mathrm{P}_{4}$ treatment as given in Figure 10. 


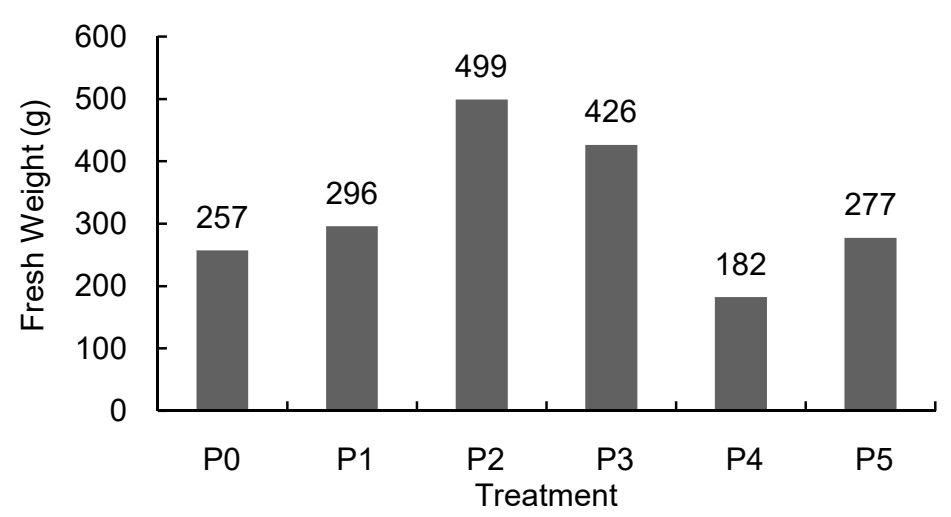

Figure 8 - The application of organic materials on plant fresh weight per clump of edible canna

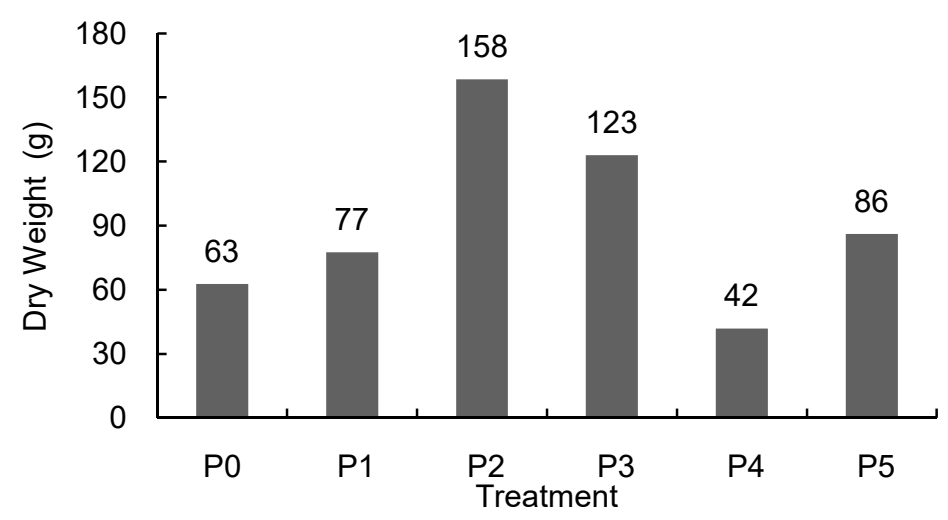

Figure 9 - The application of organic materials on plant dry weight per clump of edible canna

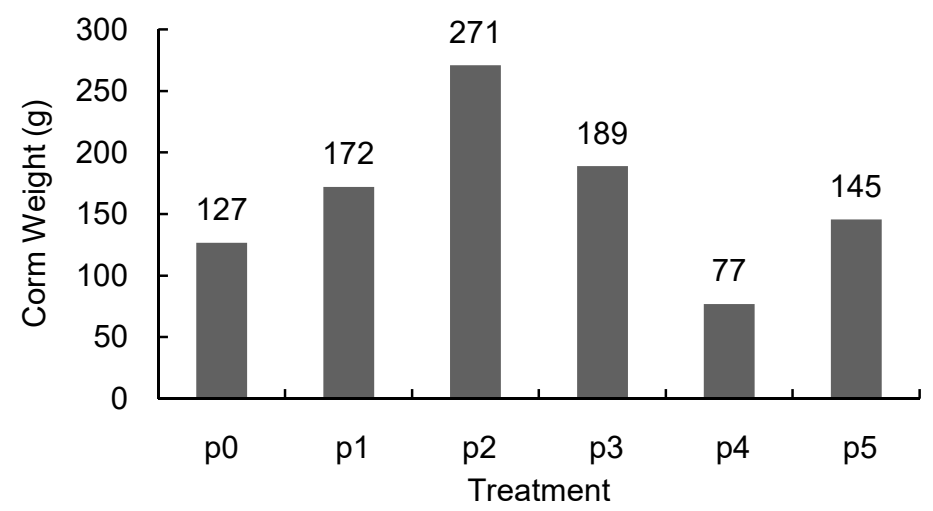

Figure 10 - The application of organic materials on corm weight per clump of edible canna

\section{DISCUSSION OF RESULTS}

Results showed that the application of organic materials did not have any signficant effect to most of parameters observed. Only flowering time had shown significant response to the treatments (Table 1). Based on soil analysis, it was found there was high Fe content in the idal swamp soil (data not shown). Thus, the added organic materials had less impact in improving soil nutrient content. However, the application of organic materials still gave better growth performance compared to control. The increasing trend of plant height and leaf number were also obtained where $\mathrm{P}_{2}$ showed better performance compared to other treatments (Figure 3 and Figure 5).

Results showed that the application of $\mathrm{P}_{2}$ treatment (15 ton ha $\mathrm{h}^{-1}$ of rice husk ash) showed the fastest bud initiation time with an average of 8 days after planting, followed by 
$P_{3}, P_{0}, P_{1}$, and $P_{4}$ while the slowest was $P 5$ with 12 days after planting (Figure 1). Similar to this, $P_{2}$ also showed better performance in plant height and tiller number with $87.42 \mathrm{~cm}$ and 5 tillers. This was probably caused by more nutrient supply from the application of rice husk ash as also reported by Nugroho (2009). Based on soil analysis results, nutrients content in $\mathrm{P}_{2}$ treatment consisted of $0.50 \%$ total $\mathrm{N}, 2.11 \mathrm{mg} \mathrm{g}^{-1} \mathrm{P}_{2} \mathrm{O}_{5}, 2.06 \mathrm{mg} \mathrm{g}^{-1} \mathrm{~K}_{2} \mathrm{O}$, and 9739.49 $\mathrm{ppm} \mathrm{Fe}$ with 3.52 of $\mathrm{pH}$. Then it was understandable that despite of high Fe content, the application of rice husk ash supplied more nutrients to the soil. Furthermore, Wahjunie (2003) added that the application of organic materials would improve soil hardening to medium level, increase the stability of soil aggregate, decrease surface sealing, and also increase infiltration rate.

On the parameter of leaf number, the highest leaf number was obtained from $\mathrm{P}_{3}$ treatment (20 ton ha ${ }^{-1}$ of rice husk ash) with 9.13 leaves in average. From these results, both $\mathrm{P}_{2}$ and $\mathrm{P}_{3}$ had showed better performance in vegetative growth parameters. These two treatments used rice husk ash as the organic materials sources. This finding was similar to a study by Dharmaswara (2012) reporting that the application of 1 ton per ha dosage of husk ash would increase vegetative growth components. High ratio of silica for about $87 \%-97 \%$ alongside with $1 \% \mathrm{~N}$ and $2 \% \mathrm{~K}$ was contained in husk ash as reported by Martanto (2001).

$\mathrm{P}_{2}$ treatment also showed the fastest flowering time with 95 days after planting followed by $\mathrm{P}_{3}$ with 96 days (Table 2). Silica content in rice husk ash was believed would increase the capacity and binding ability of $P$ to be more available in soil for plants (Soil Research Agency, 2010). In contrast, $\mathrm{P}_{2}$ treatment showed the lowest result in leaf chlorophyll with only $12.79 \mathrm{mg} \mathrm{g}^{-1}$. The best result was in $\mathrm{P}_{4}$ (10 ton ha- ${ }^{-1}$ of rice husk) with 16.78 followed by $\mathrm{P}_{3}$, $\mathrm{P}_{0}, \mathrm{P}_{5}, \mathrm{P}_{1}$ (Figure 7). However, the difference among treatments was non significant. Fageria (2009) reported Fe toxicity syndrom in rice was shown by the decrease in leaf chlorophyll, plant height and tiller number. Fe toxicity was commonly occurred in ultisol, oxisol and tidal acid sulphate soil with low $\mathrm{pH}$ and high active Fe ratio (Sahrawat, 2004).

Highest results was also obtained from $\mathrm{P}_{2}$ treatment in both plant fresh weight and plant dry weight with $499 \mathrm{~g}$ and $158 \mathrm{~g}$, respectively. Nutrients and water absorption would heavily affect plant fresh weight while the root was the beneficial organ functioning in the absorption process (Rohmah and Saputro, 2016). Research finding by Mehraban et al. (2008) reported that high percentage of the decrease in root dry weight due to Fe toxicity was correlated to the accumulation of $\mathrm{Fe}^{2+}$ in plants which in turn would decrease plants' growth. $\mathrm{P}_{2}$ treatment constantly gave better results compared to other treatments. The highest corm weight per clump was $271 \mathrm{~g}$ resulted from $P_{2}$ treatment followed by $P_{3}, P_{1}, P_{5}$, and $P_{0}$, while the lowest was in $P_{4}$ with $77 \mathrm{~g}$ (Figure 10). Goldsworthy and Fisher (1992) stated that organic fertilizer addition would indirectly encourage root growth in all normal root depths and could even trigger a better tuber formation.

\section{CONSLUSION}

It was concluded that $\mathrm{P}_{2}$ treatment (15 ton ha ${ }^{-1}$ of rice husk ash) was considered as the best treatment as indicated by having the fastest bud initiation time with 8 days after planting, highest plant height with $87.42 \mathrm{~cm}$, fastest flowering time with 95 days after planting, the most number of tiller with 5 tillers, and highest in all plant fresh weight, plant dry weight, and corm weight with $499 \mathrm{~g}, 158 \mathrm{~g}$, and $271 \mathrm{~g}$, respectively. Further research was suggested to evaluate more suitable dosage combination of organic materials application on edible canna plant in tidal swamp.

\section{REFERENCES}

1. Agricultural Land Research and Development Center. 2011. State of the art and grand design of swampland development. Agricultural Land Research and Development Center, Bogor.

2. Andayani and L. Sarido. 2013. Growth and yield of chilli (Capsicum annum L.) to four types of manure. J. Agrifor. 7 (1): $22-29$. 
3. Das, K., R. Dang, T.N. Shivananda, and N. Sekeroglu. 2007. Comparative efficiency of bio and chemical fertilizers on nutrient contents and biomass yield in medical plant Stevia rebaudiana Bertoni. J. Food Science. Technology. 1(3): 35-39.

4. Dharmaswara, I. 2012. Growth and yield of soybean on the application of husk ash fertilizer in tidal swamp land. IPB.

5. Fageria, N. K. 2009. The Use of Nutrients in Crop Plants. CRC Press. Boca Raton, Florida. pp 301- 325.

6. Goldsworthy, P.R. and N.M. Fisher. 1992. Fisiologi Tanaman Budidaya Tropik (The physiology of tropical field crops). Yogyakarta: Gadjah Mada University Press.

7. Haryono. 2013. Swampland: the future food producer for Indonesia. IAARD Press, Jakarta.

8. Ismail, M. S. and A.M. Waliuddin. 1996. Effect of Rice Husk Ash on High Strength Concrete. Construction and Building Materials. 10 (1):521 - 526.

9. Martanto. 2001. The effect of husk ash on plant growth and the intensity of Fusarium disease on tomato. J. Irian Jaya Agro 8: 37-40.

10. Mehraban, P., A.A. Zadeh, and H.R. Sadeghipour. 2008. Iron toxicity in rice (Oryza sativa L.) under different potassium nutrition. Asian J. Plant Sci. 7:251-259.

11. Novia, N. 2015. The effect of cow manure dosages on growth and yield of sweet potato (Ipomea batatas L.). Undergraduate Thesis. Faculty of Agriculture, Andalas University. Padang.

12. Nugroho, F. 2009. The utilization of rice husk ash. http://febrynugroho.wordpress .com/2009/04/03/manfaat-abusekam-padi. Accessed on March 20, 2018.

13. Rohmah. A.F and T.B. Saputro. 2016. Growth analysis of soybean (Glycine max L.) Grobogan variety on waterlogged stress condition. J. Sains dan Seni ITS 5(2): 23373520.

14. Sahrawat, K.L. 2004. Iron toxicity in wetland rice and the role of other nutrients. J. of Plant Nutrition 27, 1471-1504.

15. Sigit, G. 1984. The effect of poultry manure and husk ash application on soil chemical properties, growth and yield of upland rice Tondano variety in jasinga red-yellow podzolic soil. IPB, Bogor.

16. Soil Research Agency. 2010. The sources of silica for agriculture. Warta Penelitian dan Pengetahuan Pertanian. 33:3. Bogor.

17. Suyatno. 2004. The application of several types and dosages of manure on growth of Ipomoea sp and Brassica juncea in Samas Beach sand soil. Buletin Penelitian Hortikultura 2(2): 59-62.

18. Wahjunie, E.D. 2003. Surface sealing-crusting, the formation and how to control. Introduction to principles of science (PPS702). Doctoral Program of IPB. 